\title{
IMPLEMENTASI KOMPETENSI INTI SATU DAN DUA KURIKULUM 2013 DALAM PEMBELAJARAN BAHASA INDONESIA SISWA KELAS VIII SMPN 1 KECAMATAN PONDOK KELAPA KABUPATEN BENGKULU TENGAH TAHUN PELAJARAN 2016/2017
}

\author{
Riyansa ${ }^{1}$, Ria Ariesta ${ }^{2}$, dan Padi Utomo ${ }^{3}$ \\ ${ }^{1,2,3}$ Program Studi Pendidikan Bahasa dan Sastra Indonesia \\ Jurusan Pendidikan Bahasa dan Seni \\ FKIP Universitas Bengkulu \\ Riyansa50@yahoo.co.id
}

\begin{abstract}
Abstrak
Tujuan penelitian ini untuk mendeskripsikan implementasi kompetensi Inti satu dan dua Kurikulum 2013 dalam pembelajaran Bahasa Indonesia siswa kelas VIII SMPN 1 Kecamatan Pondok Kelapa Kabupaten Bengkulu Tengah Tahun Pelajaran 2016/2017. Metode yang digunakan dalam penelitian ini adalah metode deskriptif kualitatif. Subjek penelitian ini adalah satu orang guru Bahasa Indonesia yang mengajar di kelas VIII SMPN 1 Kecamatan Pondok Kelapa Kabupaten Bengkulu Tengah. Teknik pengumpulan data menggunakan observasi dan wawancara. Teknik analisis data yang digunakan adalah Miles dan Huberman yang meliputi pengumpulan data, reduksi data, penyajian data, dan verifikasi data. Uji keabsahan data menggunakan uji kredibilitas yang dilakukan dengan cara triangulasi. Hasil penelitian menunjukan bahwa guru telah mengimplementasikan kompetensi inti satu/sikap spiritual melalui kegiatan mengucapkan dan menjawab salam, berdoa bersama, melaksanakan shalat di sekolah dan menjaga lingkungan hidup di sekitar sekolah. Sedangkan kompetensi inti dua/sikap sosial diintegrasikan melalui kegiatan belajar dalam kelompok, tidak mencontek atau plagiat, berbicara jujur, mengerjakan dan mengumpulkan tugas tepat waktu, patuh pada tata tertib sekolah, melaksanakan tugas individu dengan baik, berani tampil di kelas, bertanggung jawab dan menerima risiko dari tindakan yang dilakukan, menghormati orang yang lebih tua, tidak memaksakan pendapat, saling menolong untuk mencapai kesuksesan bersama, berperan aktif, bertanya, menjawab, tidak putus asa, berani mencoba menerima menolak pendapat orang lain dengan santun dan menerapkan sikap salam senyum sapa kepada sesama.
\end{abstract}

\section{Kata Kunci: Implementasi, KI-1 Sikap Spiritual, KI-2 Sikap Sosial}

\begin{abstract}
The purpose of this study is to describe the implementation of the core competencies one and two Curriculum 2013 in learning Indonesian students class VIII SMPN 1 Kecamatan Pondok Kelapa Central Bengkulu District Lessons 2016/2017. The method used in this research is descriptive qualitative method. The subject of this research is one Indonesian teacher who teaches in class VIII SMPN 1 Kecamatan Pondok Kelapa, Central Bengkulu Regency. Technique of collecting data using observation and interview. Data analysis techniques used are Miles and Huberman which includes data collection, data reduction, data presentation, and data verification. Test the validity of the data using credibility test conducted by triangulation. The results showed that the teacher has implemented the core competence of one / spiritual attitude through the activity of saying and responding
\end{abstract}


greetings, praying together, performing the prayers at school and keeping the environment around the school. While the two core competencies / social attitudes are integrated through group learning activities, not cheating or plagiarism, speaking honestly, working on and collecting tasks on time, obeying school rules, performing individual duties well, daring to perform in class, be responsible and accept The risks of action, respect for the elderly, not forcing opinions, helping each other to achieve mutual success, taking an active role, asking, answering, not despairing, daring to accept others politely and politely fellow.

\section{Keywords: Implementation, KI-1 Spiritual Attitude, KI-2 Social Attitude}

\section{PENDHAULUAN}

Seiring berjalannya waktu kurikulum di Indonesia mengalami perubahan dan perkembangan yang disesuaikan dengan kebutuhan. Oleh sebab itu proses pendidikan harus dirancang dengan baik untuk mengasah pengetahuan dan kreativitas. Kurniasih \& Berlin (2014:3) berpendapat bahwa pendidikan merupakan unsur utama dalam pengembangan manusia Indonesia seutuhnya, pengelolaan pendidikan harus berorientasi kepada bagaimana menciptakan perubahan yang lebih baik, tidak bisa dipungkiri bahwa pendidikan dan kurikulum merupakan dua hal yang tidak dapat terpisahkan dalam dunia pendidikan.

Kurikulum merupakan sebuah wadah yang akan menentukan arah pendidikan. Berhasil tidaknya sebuah pendidikan sangat bergantung dengan kurikulum yang digunakan. Kurikulum merupakan ujung tombak bagi terlaksananya pendidikan, tanpa adanya kurikulum mustahil pendidikan dapat berjalan dengan baik dan efektif sesuai yang diharapkan. Kurikulum juga diartikan sebagai sejumlah mata pelajaran yang harus ditempuh siswa dari awal belajar sampai mendapatkan ijazah. Kurniasih \& Berlin (2014:6) mengemukakan kurikulum adalah suatu perangkat yang dijadikan acuan dalam mengembangkan suatu proses pembelajaran yang berisi kegiatan-kegiatan siswa yang akan dapat diusahakan untuk mencapai suatu tujuan pembelajaran khususnya dan tujuan pendidikan secara umum.

Ismawati (2012:1) mengemukakan secara tradisional kurikulum berarti sejumlah pelajaran yang harus ditempuh siswa di sekolah atau kursus. Kurikulum diartikan sebagai sejumlah mata pelajaran atau ilmu pengetahuan yang ditempuh atau yang dikuasai siswa untuk mencapai tingkat atau ijazah tertentu. Senada dengan pendapat di atas Soedijarto (dalam Ismawati,2012:3) menyatakan bahwa kurikulum adalah segala pengalaman dan kegiatan belajar yang direncanakan dan diorganisasikan untuk siswa guna mencapai tujuan pendidikan yang telah ditetapkan oleh lembaga pendidikan.

Fadlillah (2014:16) mengemukakan Kurikulum 2013 merupakan kurikulum baru yang mulai diterapkan pada tahun pelajaran 2013/2014, kurikulum ini merupakan pengembangan dari kurikulum sebelumnya, hanya saja yang menjadi titik tekan pada Kurikulum 2013 yaitu adanya peningkatan dan keseimbangan soft skills dan hard skills yang meliputi aspek kompetensi sikap, keterampilan, dan pengetahuan. Kurikulum 2013 berusaha untuk lebih menanamkan nilai-nilai yang tercermin pada sikap dapat berbanding lurus dengan keterampilan yang diperoleh peserta didik melalui pengetahuan di bangku sekolah. Kurikulum 2013 dikembangkan untuk menyiapkan peserta didik supaya memiliki kompetensi sikap, pengetahuan dan keterampilan yang seimbang sehingga mampu beradaptasi di 
mana pun, upaya tersebut wajib diterapkan secara terintegrasi melalui kegiatan pembelajaran.

Kurikulum 2013 adalah kurikulum berbasis kompetensi, Kurikulum berbasis kompetensi adalah outcomes-based curriculum, oleh karena itu, pengembangan kurikulum diarahkan pada pencapaian kompetensi yang dirumuskan dari Standar Kompetensi Lulusan, penilaian hasil belajar dan hasil kurikulum diukur dari pencapaian kompetensi. Keberhasilan kurikulum diartikan sebagai pencapaian kompetensi yang dirancang dalam dokumen kurikulum oleh seluruh peserta didik (Kebudayaan K.P, 2013: 83).

Menurt Kurniasih \& Berlin (2014:5) mengemukakan implementasi kurikulum adalah upaya pelaksanaan atau penerapan kurikulum yang telah dirancang atau didesain. Senada dengan pendapat tersebut Abidin (2014:17) berpendaapat bahwa pembelajaran dalam konteks Kurikulum 2013 dioreintasikan untuk menghasilkan insan Indonesia yang produktif, kreatif, inovatif, dan afektif melalui penguatan sikap, keterampilan, dan pengetahuan yang terintegrasi. Pernyataan ini memberikan pemahaman bahwa empat kompetensi Kurikulum 2013 wajib diimpelemntasikan secara bersamaan dalam proses pembelajaran di sekolah supaya tidak ada lagi kompetensi yang lebih dominan atau diunggulkan dalam proses pembelajaran.

Tujuan pendidikan nasional sesuai yang diamanatkan UU No. 20 Tahun 2003 tentang Sistem Pendidikan Nasional, yaitu berkembagnya potensi peserta didik agar menjadi manusia yang beriman dan bertaqwa kepada Tuhan Yang Maha Esa, berakhlak mulia, sehat, berilmu, cakap, kreatif, mandiri, dan menjadi warga negara yang demokratis serta bertanggung jawab. Jadi, pengembangan Kurikulum 2013 dirumuskan dan dikembangkan dengan suatu optimisme yang tinggi untuk menghasilkan lulusan sekolah yang lebih cerdas, kreatif, inovatif, memiliki kepercayaan diri yang tinggi sebagai individu maupun sebagai bangsa serta toleran terhadap segala perbedaan yang ada. Hal ini juga yang mendasari pentingnya menerapkan Kurikulum 2013 dalam dunia pendidikan karena kurikulum ini menuntut agar peserta didik wajib memiliki pengetahuan, keterampilan dan sikap yang baik antara sesama manusia maupun dengan sang pencipta.

Kurniasih \& Berlin (2014:8-9) mengemukakan salah satu keunggulan Kurikulum 2013 adalah berorientasi pada pendidikan karakter dan pendidikan budi pekerti yang telah diintegrasikan kedalam semua program studi atau mata pelajaran, selain itu penentuan nilai bagi siswa bukan hanya didapat dari nilai ujian saja tetapi juga dari nilai kesopanan, religi, praktik, sikap dan nilai. Senada dengan pendapat di atas Tridhonanto \& Beranda (dalam Fitri, 2016:13) mengemukakan pendidikan karakter adalah suatu sistem penanaman nilai-nilai karakter kepada peserta didik yang meliputi komponen pengetahuan, kesadaran atau kemauan, dan tindakan untuk melaksanakan nilai-nilai tersebut. Segala sesuatu yang dilakukan oleh pendidik yang mampu mempengaruhi karakter peserta didik, maka dinamakan pendidikan karakter.

Selain itu Abidin (2013:56) mengemukakan bahwa pendidikan karakter dimaknai sebagai pendidikan yang mengembangkan nilai karakter pada diri peserta didik sehingga mereka memiliki nilai dan karakter sebagai karakter dirinya, menerapkan nilai-nilai tersebut dalam kehidupan dirinya, sebagai anggota masyarakat dan warga negara yang religius, nasionalis, produktif dan kreatif. Adapun pendapat lain yang dikemukakan oleh Khoesoema (dalam Kurniasih \& Berlin, 2014:102) pendidikan karakter bukan sekedar memiliki dimensi integratif, dalam arti mengukuhkan moral intelektual peserta 
didik sehingga menjadi personal yang kokoh dan tahan uji, melainkan juga bersifat baik secara personal maupun sosial, pendidikan karakter menjadi sebuah jalan keluar bagi sebuah proses perbaikan dalam masyarakat. Situasi sosial yang ada menjadi alasan utama agar pendidikan karakter segera dilaksanakan dalam lembaga pendidikan.

Berdasarkan pendapat tersebut kelebihan pada Kurikulum 2013 tersebut mampu terealisasi apabila sikap spiritual, sikap sosial, pengetahuan, keterampilan diintegrasikan secara bersamaan dalam pembelajaran. Peraturan Pemerintah Republik Indonesia Nomor 32 tahun 2013 tentang perubahan atas Peraturan Pemerintah Nomor 19 Tahun 2005 tentang Standar Nasional Pendidikan disebutkan bahwa kompetensi adalah seperangkat sikap, pengetahuan, keterampilan, yang harus dimiliki, dihayati, dan dikuasai oleh peserta didik setelah mempelajari suatu muatan pembelajaran, menamatkan sesuatu program, atau menyelesaikan satuan pendidikan tertentu (Fadillah,2014:35).

Kompetensi inti satu KI-1 (sikap spiritual) yaitu sikap yang berkaitan dengan pembentukan peserta didik untuk beriman dan bertakwa kepada Tuhan Yang Maha Esa, sikap ini ditunjukan dengan melakukan ibadah. Kegiatan yang paling efektif untuk melatih peserta didik melaksanakan perintah Tuhan dan meninggalkan larangan Tuhan sesuai ajaran agama masing-masing. Selain itu Abidin (2013:67-70) mendeskripsikan nilai religius merupakan sikap dan perilaku yang patuh dalam melaksanakan ajaran agama yang dianutnya, toleran terhadap pelaksanaan ibadah agama lain dan hidup rukun dengan agama lain.

Sedangkan Kompetensi inti dua (sikap sosial) berhubungan dengan pembentukan sikap sosial peserta didik agar nantinya menjadi manusia yang berperilaku jujur disiplin, bertanggung jawab, peduli (gotong-royong, kerja sama, toleran, damai), santun responsif dan proaktif dalam menyelesaikan permasalahan serta membangun hubungan secara harmoni dengan lingkungan sosial dan alam sekitarnya (Niampe, 2015:99).

Kurikulum 2013 ini memang masih bisa dikatakan kurikulum baru yang mengisyaratkan kepada pendidik, satuan pendidikan, maupun pihak-pihak yang berkecimpung di dunia pendidikan wajib mengenal dan memahami seluk-beluknya. Oleh karena itu di dalam pembelajaran formal khususnya pendidik dan peserta didik harus mampu menerapkan hal-hal yang bernilai positif dalam proses pembelajaran, di antara empat kompetensi inti yang wajib diterapkan dalam pembelajaran ini kebanyakan pendidik hanya memfokuskan pada $\mathrm{KI}-3$ dan $\mathrm{KI}-4$ yaitu pada ranah pengetahuan dan keterampilan. Hal ini mengakibatkan masih banyaknya peserta didik yang memiliki pengetahuan dan keterampilan yang memadai tapi tidak memiliki sikap spiritual dan sikap sosial yang baik dalam kehidupan.

Fenomena ini merupakan masalah yang wajib diselesaikan, agar KI-1 yang mengajarkan bagaimana cara menghargai dan menghayati ajaran agama yang dianutnya, serta $\mathrm{KI}-2$ yang mengajarkan bagaimana peserta didik berperilaku jujur, bersikap disiplin, tanggung jawab, peduli (toleransi, gotong royong), santun, percaya diri, dalam berinteraksi secara efektif dengan lingkungan sosial dan alam dalam jangkauan pergaulan dan keberadaannya mampu diterapkan secara sempurna.

Kenyataanya di dunia pendidikan sekarang ini masih ditemukan fenomena dalam menerapkan kompetensi inti (KI) pada ranah sikap belum di implementasikan secara maksimal. Lagi-lagi pendidik pada umumnya hanya menitik beratkan pembelajaran pada ranah (KI-3) dan (KI-4) saja, banyak pendidik yang masih bingung bahkan sama sekali tidak mengintegrasikan dan memperhatikan kompetensi inti satu dan inti dua Kurikulum 2013 yaitu pada 
siskap spiritual dan sikap sosial, sehingga siswa tidak mendapatkan pengalaman dan ilmu yang memadai mengenai sikap spiritual dan sikap sosial. Padahal dari kompentesi inti inilah peserta didik memiliki karakter yang baik dalam pembelajaran di sekolah maupun ketika berhubungan dengan masyarakat.

Selain itu masih banyak peserta didik yang belum merasakan akan nilai-nilai religius atau keagamaan dan nilai-nilai sosial didalam lingkungan di mana mereka berada, sikap dan tingkah laku mereka belum mencerminkan pembelajaran kurikulum 2013 yang semestinya. Kurikulum 2013 banyak sekali kelebihan dan kekurangannya namun semua itu bukanlah hal yang bisa dijadikan alasan guru tidak mengintegrasikan kompetensi inti satu dan dua dalam pembelajaran, guru yang profesional hendaknya siap dan bersikap posistif serta mampu menyesuaikan pembelajaran yang baik, berinovasi, kreatif sesuai kebutuhan sekolah dan tujuan Kurikulum 2013.

Kompetensi inti dan kompetensi dasar didalam Kurikulum 2013 memang bisa dikatakan sesuatu yang sangat baru untuk diterapkan di sekolah maka dari itu penulis tertarik untuk melakukan penelitian tentang Implementasi Kompetensi Inti Satu Dan Dua Kurikulum 2013 Dalam Pembelajaran Bahasa Indonesia Siswa Kelas VIII SMPN 1 Kecamatan Pondok Kelapa Kabupaten Bengkulu Tengah Tahun Pelajaran 2017/2018, hal ini di maksudkan untuk mengetahui implementasi $\mathrm{KI}-1$ dan $\mathrm{KI}-2$ Kurikulum 2013 dalam proses pembelajaran bahasa Indonesia di sekolah.

\section{METODE}

Penelitian ini mengunakan metode deskriptif dengan pendekatan kualitatif. Penelitian kualitatif ditujukan untuk memahami fenomena-fenomena sosial dari sudut pandang partisipan. Dengan demikian penelitian kualitatif adalah penelitian yang digunakan untuk meneliti pada kondisi objek alamiah di mana peneliti merupakan instrumen kunci dalam penelitian (Sugiyono,2014:7-8). Pendapat lain disampaikan Susetyo (2015:11) penelitian deskriptif adalah penelitian yang dilakukan apabila peneliti ingin menjawab persoalanpersoalan tentang gejala-gejala yang ada atau berlaku pada masa sekarang".

Penelitian ini dilaksanakan di SMPN 1 Kecamatan Pondok Kelapa Kabupaten Bengkulu Tengah, pada siswa kelas VIIIA, VIIIB, VIIIC, yang terdiri dari 25-30 siswa dalam satu kelasnya. Waktu yang digunakan dalam penelitian ini yaitu pada saat proses pembelajaran Bahasa Indonesia siswa kelas VIII semester genap, selama satu bulan mulai dari tanggal 13 Februari sampai 13 Maret Tahun Pelajaran 2016/2017.

Data dalam penelitian ini adalah fenomena yang sesuai dengan objek penelitian. berupa ujaran guru dan siswa serta fenomena yang mampu diamati yang berkaitan dengan sikap spiritual dan sikap sosial pada kegiatan pembelajaran siswa kelas VIII yang terlibat dalam proses pembelajaran Bahasa Indonesia dengan Kurikulum 2013.

Teknik pengumpulan data dalam penelitian ini menggunakan teknik observasi nonpartisipan dan teknik wawancara tidak terstruktur. Teknik analisis data yang digunakan yaitu teknis analisis data kualitatif, Miles \& Huberman (dalam Sugiono,2014:246) mengemukakan bahwa aktivitas dalam analisis data kualitatif dilakukan melalui beberapa tahap yaitu: 1 . Data Reduction (Reduksi Data), 2. Data Display (Penyajian Data), 3. Conclusion Drawing/verification.

Penelitian ini menggunakan instrumen atau alat penelitian yaitu peneliti itu sendiri, penelitilah sebagai alat penelitian utama. Peneliti sendiri yang melakukan pengamatan secara detail (untuk memilih informan, mengumpulkan data, menilai kualitas data, menganalisis data, 
menafsirkan data, dan menyimpulkan atas temuan) dan wawancara pada guru dan siswa (Sugiyono,2014:222).

Validasi data dalam penelitian ini menggunakan triangulasi sumber dan triangulasi teknik, sumber yang dimaksud misalnya, menanyakan kebiasaan belajar siswa, tidak hanya bertanya kepada siswa tetapi juga bisa bertanya kepada guru, teman, dan orang tua. Metode megumpulkan data yang beragam digunakan seperti tidak hanya cukup dengan wawancara dan kelompok fokus.

\section{HASIL DAN PEMBAHASAN}

\section{Kompetensi Inti Satu (KI-1)}

Sikap religius Kurikulum 2013 dalam pembelajaran Bahasa Indonesia telah diimplementasikan dengan baik oleh guru pada siswa kelas delapan, melalui berbagai kegiatan pembelajaran yang disusun dan diterapkan di lingkungan sekolah. Guru mencoba dengan seluruh kemampuannya untuk menerapkan sikap religus secara maksimal agar siswa memilki sikap dan perilaku yang baik serta mampu menghargai dan menghayati ajaran agama yang dianutnya untuk diterapkan dalam kehidupan sehari-hari.

Niampe (2015:98) kompetensi sikap spiritual yang terkait dengan pembentukan sikap peserta didik untuk beriman dan bertakwa kepada Tuhan Yang Maha Esa, sikap ini ditunjukan dengan melakukan ibadah. Selain itu Abidin (2013:67-70) mendeskripsikan nilai religius merupakan sikap dan perilaku yang patuh dalam melaksanakan ajaran agama yang dianutnya, toleran terhadap pelaksanaan ibadah agama lain dan hidup rukun dengan agama lain.

Kegiatan rutin yang selalu dilaksankan oleh guru dalam menerapkan sikap religius dalam pembelajaran yaitu: (1). Mengucapkan salam "Assalamualaikum wr. Wb." sebelum dan setelah melaksanakan kegiatan pembelajaran sesuai agama yang dianutnya, (2). Berdoa sebelum dan sesudah mengikuti pembelajaran, (3) Membiasakan mengucapkan syukur ketika selesai mengikuti pelajaran dan ketika berhasil mengerjakan tugas, (4). Melaksanakan ibadah shalat di sekolah, (5). Menjaga lingkungan hidup di sekitar kelas/sekolah.

Sikap spiritual ini di maksudkan agar peserta didik memiliki moral atau etika yang baik dalam kehidupannya, selain itu sikap ini merupakan perwujudan hubungan antara seseorang hamba dengan Tuhan Yang Maha Esa. (Fadillah,2014:49).

\section{Kompetensi Inti Dua (KI-1)}

Seperti yang disampaikan Fahrudin (2014:8) sikap sosial adalah orang-orang yang dapat berealisasi dengan orang lain dan lingkungannya dengan baik. Sikap ini wajib dilakukan oleh peserta didik dalam kehidupan sehari-hari, baik di sekolah maupun di tempat dimana peserta didik berada. Berikut ini kegiatan yang dilakukan guru dalam mengintegrasikan sikap sosial kepada siswa dalam proses pembelajaran bahasa Indonesia:

\section{a. Sikap Jujur}

Niampe (2015:152) mengemukakan sikap jujur adalah perilaku yang dapat dipercaya dari perkataan, tindakan, pekerjaan, sikap ini melambangkan keperibadian yang mewarnai tingkah laku seseorang sehingga harus dikembangkan pada diri peserta didik dan proses mengembangkan sikap jujur dalam pembelajaran dilakukan secara terintegrasi dengan semua mata pelajaran. Berdasarkan hasil observasi dan wawancara sikap jujur diterapkan oleh guru melalui aktivitas pembelajaran Bahasa Indonesia dikelas, seperti pada kegiatan berikut ini: (1). Mengerjakan tugas dengan baik dan tidak menyontek, (2). Berbicara dengan jujur, (3). Membuat tugas berdasarkan data atau informasi yang benar dan nyata, (4). Tidak membenarkan melakukan plagiatisme (mengambil/ 
menyalin karya orang lain tanpa menyebutkan sumber), (5). Bersyukur atas nikmat dan karunia Tuhan Yang Maha Esa atas diberikannya Bahasa Indonesia untuk berkomunikasi

\section{b. Disiplin}

Salah satu tujuan dari pendidikan yaitu agar siswa menjadi terdidik dan memiliki jiwa disiplin, senada dengan hal tersebut Niampe (2015:154) mengemukakan sikap disiplin adalah tindakan yang menunjukan perilaku tertib dan patuh pada berbagai ketentuan dan peraturan yang berlaku, baik yang tertulis maupun tidak tertulis. Berdasarkan hasil observasi dan wawancara guru mengintegrasikan sikap disiplin ke dalam pembelajaran melalui kegiatan berikut ini: (1). Datang ke sekolah dan masuk kelas tepat waktu. Guru memberikan teladan kepada siswa untuk datang lebih awal, 10 menit sebelum jam pelajaran dimulai, (2). Patuh pada tata tertib atau aturan bersama/sekolah. Guru memberikan teladan datang mengajar dan mengikuti kegiatan sekolah tepat waktu, guru memberikan peringatan kepada siswa jika terlambat agar tidak mengulanginya lagi, lalu siswa di izinkan mengikuti pelajaran ketika siswa telah berjanji tidak mengulangi ke salahannya, (3). Mengerjakan/ mengumpulkan tugas sesuai dengan waktu yang ditentukan.

\section{c. Tanggung Jawab}

Abidin (2013:68) yang mengemukakan tanggung jawab merupakan sikap dan perilaku seseorang untuk melaksanakan tugas dan kewajibannya. Hasil observasi dan wawancara sikap tanggung jawab diterapkan oleh guru kepada siswa melalui kegiatan pembelajaran berikut ini, (1). Melaksanakan tugas individu dengan baik. Guru memberikan tugas secara individu untuk membaca, mengidentifikasi dan menuliskan serta menyusun "Cerita ulang sang pemimpi, laskar pelangi dan cerpen nasehat untuk anakku" sesuai dengan langkahlangka menysun teks ulasan (ada pada lampiran RPP), (2). Berani menerima risiko dari tindakan yang dilakukan. Guru memberikan tugas untuk mengidentifikasi dan menuliskan serta "Menyusun cerita ulang Sang Pemimpi, Laskar Pelangi dan cerpen Nasehat Untuk Anakku, siswa akan diberi nilai yang baik bagi kalau tugasnya dikerjakan secara maksimal, dan guru akan memberikan nilai yang kurang baik ketika siswa main-main dalam mengerjakan tugas yang diberikan, (3). Bertanggung jawab terhadap barang yang dipinjam baik itu barang orang lain maupun sekolah. Guru memberikan saran kepada siswa supaya buku pelajaran pinjaman dari sekolah untuk di rawat dan diberi sampul/kafer tambahan agar tidak mudah rusak, "Perhatikan dulu, untuk minggu depan ibu tidak mau lagi melihat buku pelajaran belum di bungkus rapi, semuanya wajib menjaga buku pinjam ini agar tidak rusak", siswa menerima saran guru dan dan bertanggung jawab atas barang (buku cetak) yang di pinjamnya dari sekolah untuk dijaga dan di bungkus dengan pembungkus tambahan seperti kertas manila, kertas kado dan kertas lainnya, (4). Wajib mengakui dan meminta maaf atas kesalahan yang dilakukan, guru akan memanggil siswa yang mencontek dalam mengerjakan tugas dan meminta mereka meminta maaf atas kesalahannya sebelum melanjutkan mengerjakan tugas yang diberikan guru " $R$ kenapa tugas kamu sama persis dengan tuga $P$ ? Maaf buk saya pinjam tuganya $R$, ibu mau kamu minta maaf 
sama teman kamu, ya buk...." siswa yang di tegur oleh guru tersebut menundukkan kepala sambil meminta maaf dan mengakui kesalahannya dengan berjanji tidak akan mengulanginya lagi, (5). Menepati/melaksanakan apa yang pernah dikatakan tanpa di minta/disuruh. Guru memberi contoh menepati janji dalam pembelajaran guru memberi nilai bagus kepada siswa yang mengerjakan tugas dengan maksimal, seluruh siswa berlombalomba berusaha mengerjakan tugas dengan baik agar mendapat nilai besar dari guru, guru dan siswa juga mengikuti kegiatan belajar mengajar tanpa diminta atau disuruh oleh kepala sekolah.

\section{d. Toleransi}

Niampe (2015:159) sikap toleransi adalah sikap dan tindakan menghargai keberagaman latar belakang, pandangan dan keyakinan serta toleransi ini memandang keberagaman sebagai satu kekuatan. Hasil observasi dan wawancara pada sikap saling menghargai sudah diterapkan oleh guru kepada siswa melalui kegiatan pembelajaran berikut ini: (1). Menghargai pendapat/ keputusan serta menerima kelebihan dan kekurangan orang lain, dari hasil observasi pada kegiatan pembelajaran, guru membentuk empat kelompok secara acak masing-masing anggotanya terdiri dari lima sampai enam orang kegiatan seperti ini di maksudkan agar siswa mendapatkan pengalaman belajar lebiah banyak dari berbagai sumber pengetahuan yang dimiliki oleh setiap anggota kelompok, pada saat ada siswa yang diberi pertannyaan namun tidak bisa menjawabnya, siswa dalam anggota kelompoknya akan mencoba membantu menjawab pertanyaan tersebut, (2). Mememaafkan kesalahan orang lain, guru memberi contoh kepada siswa pada akhir pembelajaran untuk mengucapkan maaf atas katakata kurang baik yang mungkin terucap dalam mengajar, siswa menganggukan kepala tanda merespon maaf yang di sampaikan guru atas ucapannya yang kurang baik yang mungkin terjadi pada saat penyampaian materi pembelajarann, (3). Mengajarkan untuk terbuka menerima masukan serta mampu dan mau bekerja sama dengan siapa pun yang memiliki keberagaman latar belakang, pandangan, dan keyakinan, guru mendorong siswa agar kompak dalam menyelesaikan tugas kelompok yaitu mengidentifikasi dan menuliskan serta menyusun "Cerita Ulang Sang Pemimpi, Laskar Pelangi dan cerpen Nasehat Untuk Anakku" sesuai dengan langkah-langka menysun teks ulasan (ada pada lampiran RPP, siswa mengajak temannya yang tidak membawa buku pelajaran agar bergabung belajar bersama. Seluruh siswa terlihat rukun dan saling menghargai satu sama lain dalam belajar di kelompoknya masing-masing.

\section{e. Gotong Royong}

Niampe (2015:161) yang menjeaskan sikap gotong royong adalah sikap suka bekerjasama dengan orang lain secara ikhlas untuk kepentingan bersama, berbagai tugas, dan saling membantu dalam penyelesaian tugas. Hasil observasi dan wawancara pada sikap gotong royong sudah diterapkan oleh guru kepada siswa melalui kegiatan pembelajaran yaitu: (1). Terlibat dalam kerja bakti membersihkan kelas atau sekolah. Guru dan siswa terlibat dalam menjaga lingkungan sekolah, guru meminta siswa agar membersihkan kelas sesuai jadwal piket secara kelompok, agar kebersihan lingkungan kelas terjaga, (2). Bekerja secara 
kelompok untuk mencapai tujuan bersama, guru berkeliling kesetiap kelompok memberikan bimbingan kepada siswa yang mengalami kesulitan dalam memahami materi ataupun tugas yang diberikan, siswa meminta guru membimbing mereka dalam mengerjakan tugas kelompok yaitu mengidentifikasi dan menuliskan serta menyusun "Cerita Ulang Sang Pemimpi, Laskar Pelangi dan cerpen Nasehat Untuk Anakku" sesuai dengan langkahlangka menysun teks ulasan (ada pada lampiran RPP), siswa bertanya kepada guru mengenai tugas yang diberikan, (3). Saling menolong dan membantu untuk mencapai kesuksesan bersama dengan memberikan tugas kepada siswa untuk mengidentifikasi dan menuliskan serta menyusun "Cerita Ulang Sang Pemimpi, Laskar Pelangi Dan Cerpen Nasehat Untuk Anakku" sesuai dengan langkah-langka menysun teks ulasan (ada pada lampiran RPP, sesuai dengan langkah-langka menysun teks ulasan, untuk melatih rasa tolong menolong di antara siswa. Seluruh siswa dengan kelompok belajarnya masingmasing bersama-sama mengerjakan tugas untuk mencapai tujuan dan kesuksesan bersama.

\section{f. Sopan atau santun}

Niampe (2015:164) mengemukakan sikap sopan santun adalah sikap baik dalam pergaulan, baik dalam berbahasa maupun dalam bertingkah laku sesuai situasi dan kondisi. Hasil observasi dan wawancara pada sikap soapan santun sudah diterapkan oleh guru kepada siswa melalui kegiatan pembelajaran berikut ini: (1). Menghormati guru didalam kelas, sikap siswa terhadap guru sangat hormat, guru mengajarkan siswa untuk menghormati orang yang lebih tua dengan memberi kesempatan siswa untuk berjabat tangan dan memberikan salam kepada dirinya, begitu juga guru yang muda akan memberi salam dan berjabat tangan dengan guru yang lebih tua sebagai rasa hormat untuk mereka, siswa juga terbiasa ketika sudah mengikuti proses pembelajaran memberi salam dan bersalaman kepada guru, guru menjawab salam dari siswa itu dan sambil seyum kepada seluruh siswa, (2). Tidak berkata kotor, kasar, dan takabur selain itu guru juga melarang siswa melakukan tindakan jorok, cabul, dan perbuatan negatif lainnya, pada saat melakukan observasi dan wawancara tidak ada ditemukan guru dan siswa melakukan tindakan negatif/jorok, (3). Memperlakukan orang lain seperti memperlakukan diri sendiri, guru mengajarkan siswa agar tidak menyela pembicaraan pada waktu yang tidak tepat, siswa boleh bertanya setelah guru atau temannya yang lebih dulu di beri kesempatan bertanya barulah secara bergantian mereka berbicara atau bertanya dari materi yang di jelaskan tadi yang belum di mengerti, siswa juga secara bergantian menyampaikan kesimpulan atas materi yang telah di pelajari, (4). Mengucapkan terima kasih setelah menerima bantuan orang lain dengan memberikan waktu kepada siswa untuk mengucapkan terimakasih "Terima kasih buk" yang ditujukan kepada guru pada akhir pembelajaran yang dipimpin oleh siswa yang bertugas sebagai ketua kelas, (5). Menerapkan sikap salam, senyum, sapa kepada sesama dengan memberi contoh menyapa siswa dengan salam dan memanggil nama mereka pada saat memeriksa daftar hadir, siswa menjawab salam dari guru, membalas senyum guru, dan merespon ketika guru memanggil nama, begitu juga sikap guru terhadap siswa, guru tersenyum ketika bertemu dengan siswa dan menjawab salam siswa dengan nada dan muka yang baik, (6). Meminta izin ketika akan 
memasuki/keluar ruangan atau menggunakan barang milik orang lain, guru mengajarkan siswa untuk tertib agar meminta izin ketika ingin keluar atau masuk ke ruang kelas. Siswa mengangkat tangan sambil mengucapkan "Permisi buk, saya mau keluar sebentar pergi ke $W C^{\prime \prime}$ ketika guru memberikan izin kepada siswa, barulah siswa tersebut.

\section{g. Percaya diri}

Niampe (2015:167) sikap percaya diri adalah situasi dan kondisi mental yang memberi kekuatan pada hati sehingga yakin terhadap sesuatu. Hasil observasi dan wawancara pada sikap percaya diri sudah diterapkan oleh guru kepada siswa melalui kegiatan pembelajaran yaitu: (1). Berani presentasi di depan kelas serta aktif memberikan pendapat atau melakukan kegiatan tanpa ragu-ragu dengan mendorong siswa agar berani tampil di depan kelas "Ayo nak siapa yang mau menyampaikan hasil bacaanya, ibu persilakan, salah juga tidak apa-apa, jangan takut" Siswa mencoba mempresentasikan tugasnya yaitu "Membaca dan mengidentifikasi serta menyusun cerita ulang Sang Pemimpi, Laskar Pelangi Dan Cerpen Nasehat Untuk Anakku" (ada pada lampiran RPP guru), siswa memberikan perpendapat sesuai dengan pemahamannya, setelah siswa selesai menyampaikan gagasannya di depan kelas guru dan siswa lainnya memberikan tepuk tangan yang meriah, (2). Mendukung agar berani memberikan kritik dan saran serta bertanya, atau menjawab pertanyaan orang lain dengan bahasa yang santun, guru menunjuk siswa yang jarang bertanya, jarang menjawab dan jarang mengemukakan pendapatnya di kelas agar memberanikan diri untuk bertanya. Siswa bersikap positif terhadap dukungan guru kepada dirinya, siswa yang dibantu guru mencoba menjawab pertanyaan, mengemukakan pendapat terhadap pertanayan atau permasalahan yang sedang didiskusikan dalam kelas sesuai pemahaman mereka mengenai materi "Mengidentifikasi dan menuliskan serta menyusun cerita ulang sang pemimpi, laskar pelangi dan cerpen nasehat untuk anakku" (ada pada lampiran RPP guru).

\section{PENUTUP}

\section{Kesimpulan}

Berdasarkan hasil penelitian yang telah dilakukan, dapat disimpulkan bahwa:

1. Pada ranah kompetensi inti satu sikap spiritual dalam pembelajaran guru mengimplementasikannya dengan kegiatan di dalam kelas seperti (1) mengucapkan salam dan syukur sebelum dan setelah melaksanakan kegiatan pembelajaran sesuai agama yang dianut. (2) berdoa bersama sebelum dan sesudah mengikuti proses pembelajaran. (3) melaksanakan ibadah shalat di sekolah. (4) menjaga lingkungan hidup di sekitar kelas/sekolah.

2. Pada ranah kompetensi inti dua sikap sosial guru mengimplementasikannya dalam proses pembelajaran melalui kegiatan belajar dalam kelompok, tidak mencontek atau plagiat, berbicara jujur, mengerjakan dan mengumpulkan tugas tepat waktu, patuh pada tata tertib sekolah, melaksanakan tugas individu dengan baik, berani tampil di kelas, bertanggung jawab dan menerima risiko dari tindakan yang dilakukan, menghormati orang yang lebih tua, tidak memaksakan pendapat, saling menolong untuk mencapai kesuksesan bersama, berperan aktif memberikan pendapat, bertanya, menjawab, tidak putus asa, berani mencoba menerima, menolak pendapat orang lain dengan santun dan menerapkan sikap salam senyum sapa kepada sesama. 


\section{Saran}

1. Bagi guru hendaknya menciptakan situasi pembelajaran yang lebih kreatif dan bervariasi agar dalam menerapakan kompetensi inti satu dan dua Kurikulum 2013 dapat di implemntasikan dengan maksimal agar seluruh siswa yang terlibat dalam proses pembelajaran lebih memaknai dan membiasakan diri menerapkan sikap religius dan sikap sosial di dalam kehidupan sehari-hari baik di sekolah maupun di lingkungan masyarakat.

2. Perlu adanya penelitian lebih lanjut yang lebih sfesifik untuk memaksimalkan penelitian yang telah dilakukan sebelumnya mengenai kompetensi sikap spiritual dan sikap sosial Kurikulum 2013 dalam pembelajaran bahasa Indonesia, agar tujuan kurikulum dalam pembelajaran dapat terlaksana dengan baik

\section{DAFTAR PUSTAKA}

Abidin, Y. 2013. Pembelajaran Bahasa Berbasis Pendidikan Karakter. Bandung: Refika Aditama.

Abidin, Y. 2014. Desain Sistem Pembelajaran Dalam Konteks Kurikulum 2013. Bandung: Refika Aditama.

Fadlillah, M. 2014. Implementasi Kurikulum 2013. Yogyakarta: AR-Ruzz Media.

Fahrudin, A. 2014. Pengantar Kesejahteraan Sosial. Bandung: Refika Aditama.
Fitri, S. 2016. Implementasi pendidikan Karakter Jujur Dan Karakter Mandiri Di Kelompok B PAUD Pertiwi 1 (Studi Deskriptif Di Kelompok B PAUD Pertiwi 1 Kota Bengkulu). Bengkulu: Fakultas Keguruan Dan Ilmu Pendidikan Universitas Bengkulu.

Ismawati, E. 2012. Telaah Kurikulum Dan Pengembangan Bahan Ajar. Yogyakarta: Ombak.

Kebudayaan, K. P. 2013. Materi Pelatihan Guru Implementasi Kurikulum 2013. Jakarta: Badan Pengembangan Sumber Daya Manusia Pendidikan dan Kebudayaan dan Penjaminan Mutu Pendidikan.

Kurniasih, I., \& Berlin. 2014. Sukses Mengimplementasikan Kurikulum 2013. Surabaya: Kata Pena.

Kurniasih, I., \& Berlin. 2014. Implementasi Kurikulum 2013 Konsep Dan Penerapan. Surabaya. Kata Pena.

Niampe, L. 2015. Kurikulum Baru Revolusi Mental Peserta Didik. Bandung: Mujahid Press.

Sugiyono. 2014. Metode Penelitian Kuantitatif Kualitatif Dan $R$ \&D. Bandung: Alfabeta. 